\title{
Challenges of Human Resource Management in Long-Distance Study Program
}

\author{
Catrina CHIVU \\ Transilvania University of Brasov, Romania, catrina.c@unitbv.ro \\ Cătălin-Iulian CHIVU \\ Transilvania University of Brasov, Romania, catalin.c@unitbv.ro
}

\begin{abstract}
Long-distance in Romania is a different concept compared to international idea about this education form. In Romania, ARACIS applied a so-called blending learning, meaning that both students and teaching staff should have activities face-to-face, more than this these will be weekend activities. This is one of the biggest challenges of managing teaching staff in these study programs. Present paper underlines challenges and give some solutions to reduce abandon rate, from teaching staff point of view.
\end{abstract}

\section{Keywords}

human resource management, high education, eLearning

\section{National Context of Distance Learning Programmes}

Romanian Law of National Education, no. 1/2011, stipulates that, on Bachelor's level, there are three types of higher education programmes in Romania: full-time undergraduate programmes, part-time undergraduate programmes and distance learning undergraduate programmes [1].

Annually, Romanian Government actualise nomenclature of domains and higher education study programmes and the structure of universities. Based on 2018 nomenclator 692/2018-09-05 [2], in Romania there are six fundamental fields which include 78 high education domains (undergraduate, graduate and $\mathrm{PhD}$ ) (Figure 1).

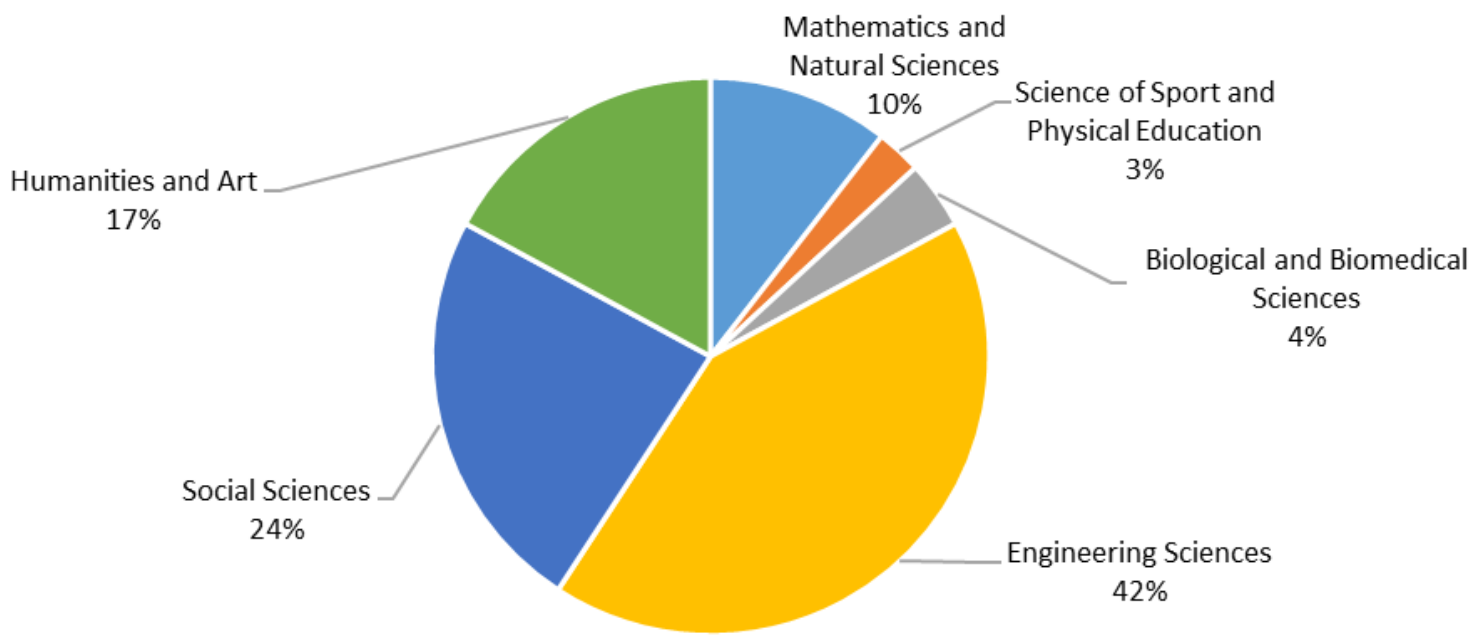

Fig. 1. Romanian high education domains [2]

According to the same nomenclator in 2018-2019 academic year, there are 55 state universities and 29 private universities. Part-time and distance learning study programmes are part of almost all universities. Thus, according to [2], analyzing the maximum number of students that can be enrolled in 2018-2019 academic year, students from part-time and distance learning are $9.64 \%$ of these from state universities and $17.99 \%$ in private universities (Figure 2 - based on data from [2]). 
RECENT, Vol. 19, no. 3(56), December, 2018

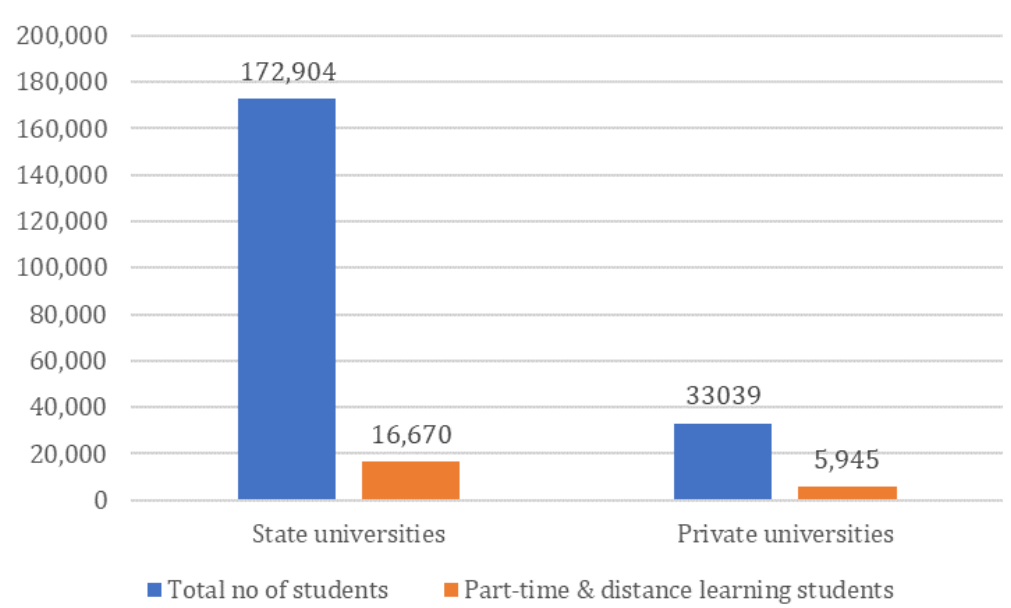

Fig. 2. Number of students enrolled in 2018-2019 academic year

Figure 3 shows first five universities as number of part-time and distance learning students enrolled in 2018-2019 academic year and Figure 4, first five universities as percentage of these students related to total number of students enrolled in 2018-2019 academic year (based on data from [2]).

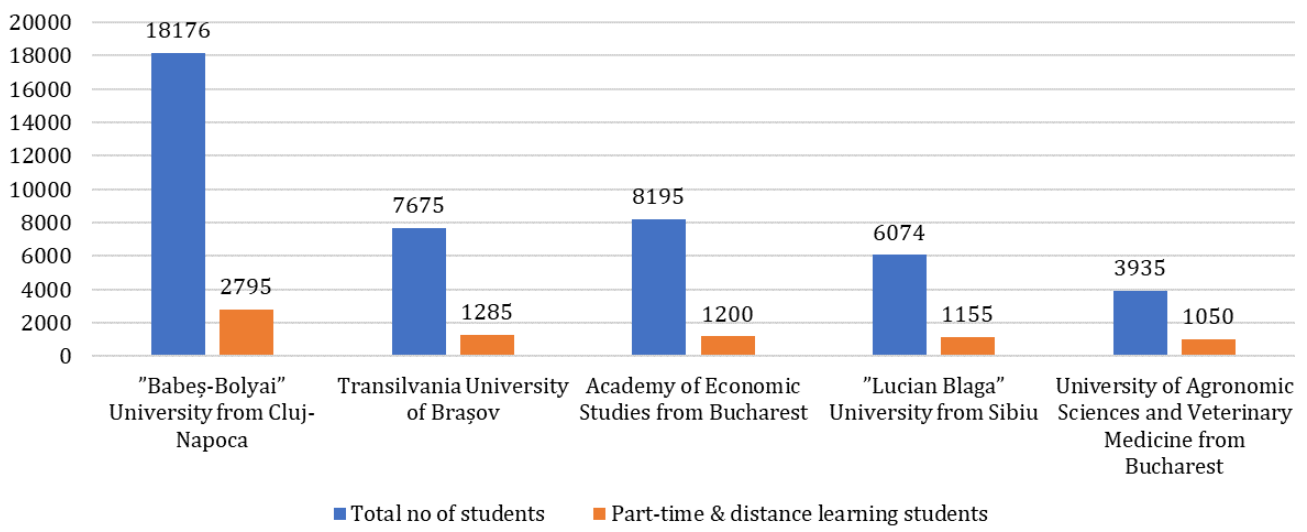

Fig. 3. First five universities as number of part-time and distance learning students enrolled in 2018-2019 academic year

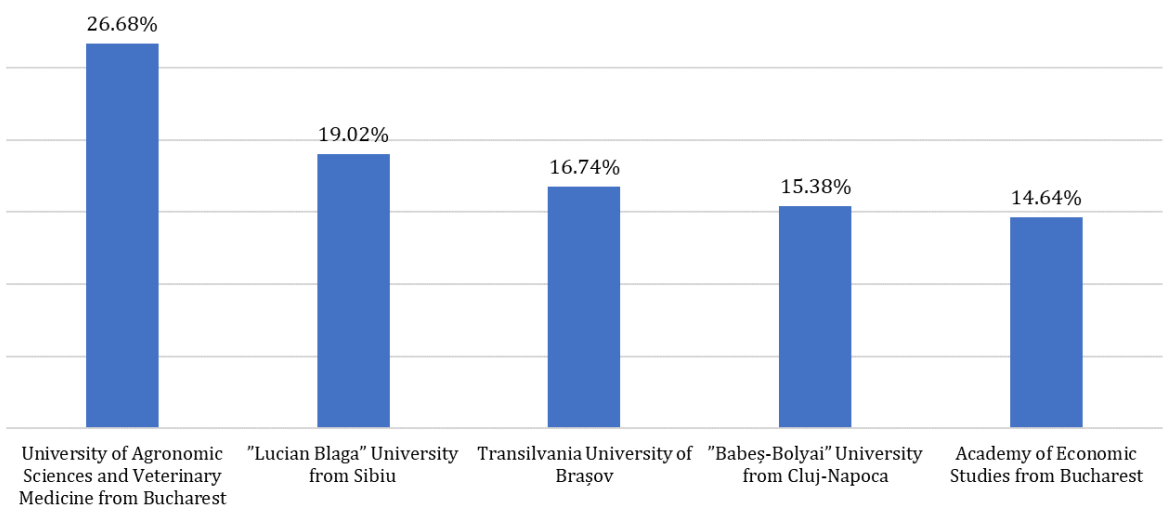

Fig. 4. First five universities as percentage of part-time and distance learning students related to total number of students enrolled in 2018-2019 academic year

Over the last four years, there has been a decrease on number of students enrolled in the first year in part-time and distance learning study programmes. Thus, if in 2014 there were enrolled in the first year 18450 students in state universities and 9745 in private universities, in 2018-2019 academic year there were only 16670 in state universities and, respectively, 5945 in private universities. Thus, as it is shown 
in Figures 5 and 6, number of students enrolled in the first year in part-time and distance learning study programmes are in a descendent line, with a decrease of $10.68 \%$ in state universities and $63.92 \%$ in private universities.

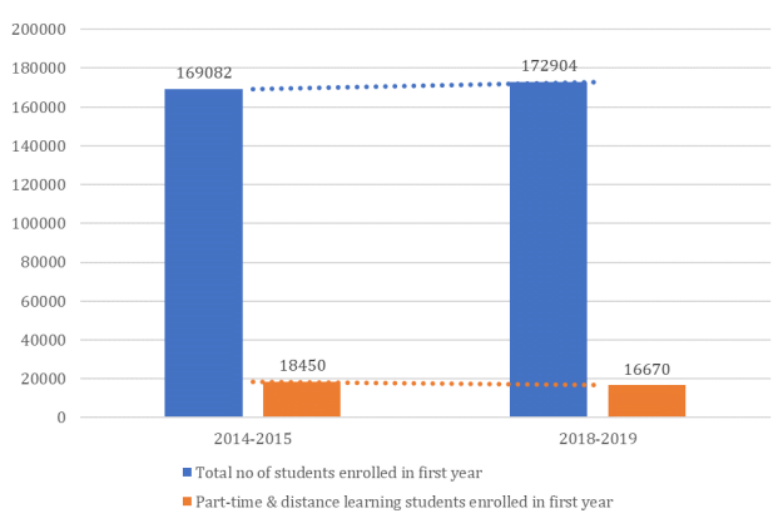

Fig. 5. Number of students enrolled in state universities

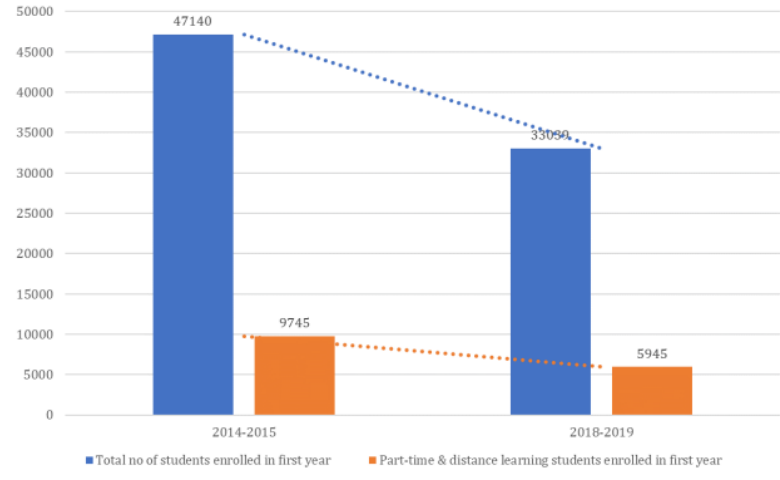

Fig. 6. Number of students enrolled in private universities

Is it a normal trend? In state universities, where the number of students increased, it should be analysed the causes, because part-time and distance learning programmes are profit-generating ones, as it will be shown in the next paragraph. In private universities the trend is a normal reaction caused by low quality of education process, which determined the loose of accreditation and a significant decrease of number of enrolled students. That is why, in the following the study is focused on state universities.

\section{Human Resource Dynamics in Part-Time and Distance Learning Study Programmes}

It was done a research in first three universities in terms of enrolled students in part-time and distance learning study programmes. Study tried to identify the dynamics of human resource in parttime and distance learning study programmes. The main purpose was to answer to the question: why the turnover rate of coordinators and teaching staff involved in these study programmes are so high?

\subsection{Coordinators dynamics analysis}

To identify rate of turnover and its causes, where determined stability index and leavers' length of service.

Stability index provides an indication of the tendency for longer-service employees to remain with the university, and therefore shows the degree to which there is continuity of employment [3]. Authors extrapolate this concept, computing stability index as:

$$
\mathrm{I}_{\text {stability }}=\frac{\text { no coordinators with } 1 \text { year's service or more }}{\text { no coordinators involved } 1 \text { year ago }} \times 100
$$

Thus, in the three studies universities there are 67 study programmes in 2018-2019 academic year with 62 coordinators (all 67 programmes started at least 3 years ago):

$$
\mathrm{I}_{\text {stability coord }-2018}=\frac{46}{62} \times 100=74.19 \%
$$

The information relative to stability can be enhanced if an analysis is also made of the average length of service of people who give up coordination. To be more relevant, study was extended on statistics of the last four years (2014-2018) (index computed on six months, one year, two years and three years) considering an average of study programmes (for the three universities) of 59 programmes and of 54 coordinators, respectively.

$$
\mathrm{I}_{\text {average }-\mathrm{x} \text { months }}=\frac{\text { no coordinators leave in } \mathrm{x} \text { months }}{\text { no coordinators involved } \mathrm{x} \text { months }} \times 100
$$

In Table 1 are presented results from the study. 
RECENT, Vol. 19, no. 3(56), December, 2018

Table 1. Average length of service of people who give up coordination

\begin{tabular}{|c|c|c|c|c|}
\hline less than 6 months & 6 months - 1 year & 1 year - 2 years & 2 years -3 years & more than 3 years \\
\hline $3.70 \%$ & $9.26 \%$ & $16.67 \%$ & $16.67 \%$ & $22.22 \%$ \\
\hline
\end{tabular}

Analysing the two indicators it can be concluded:

- stability index (rel. (2)) is a small one because coordinators of part-time and distance learning study programmes should be certificated from ARACIS in the field of distance learning. The last official certification course organised by ARACIS was in 2015. Thus, a significant number of coordinators have no certification from ARACIS, just internal one, which will cause, in accreditation documents of ARACIS, a so called "partially-fulfilled standard" indicator;

- average length of service indexes (Table 1) are very high, considering the competences of a coordinator of such programmes, relative to specific documents and, especially, relative to eLearning platform.

\subsection{Teaching staff dynamics analysis}

Turnover in the case of teaching staff, can be associated along an academic year, so, in this case, study was focused just on stability index (rel. (2)). Thus, input data were: five academic years interval average (2014 - 2018); 59 study programmes (10 of eight semesters; 53 of six semesters and six of two semesters); an average of six disciplines/semester; around 2148 disciplines; around 1200 teaching staff. Data from the study are presented in Figure 7, which is a synthesis of indexes computed based on rel. (2), extended on five academic years.

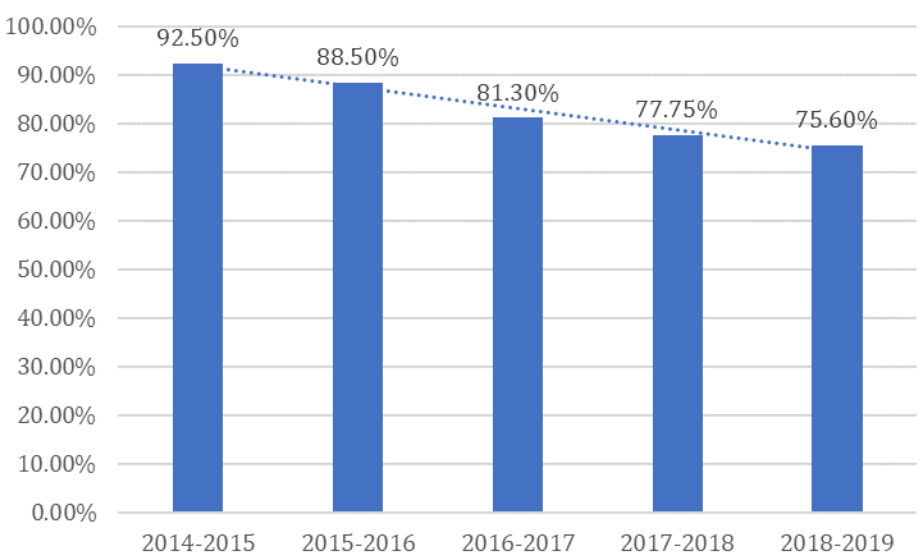

Fig. 7. Stability index for teaching staff involved in part-time and distance learning study programmes

Analysing the results, it can be concluded that there is an almost constant decrease of index, that will definitely influence the quality of didactic materials, the eLearning platform activities. The impact of this decrease will be analysed on the following paragraph.

\section{Factors That Determine Turnover}

In Romania, methodology and standards for various types of higher education programmes are provided by Romanian Agency for Quality Assurance in Higher Education [4].

In Table 2 there are compared human resources' activities (mandatory): full-time undergraduate programmes vs part-time and distance learning programmes. Activities shown in Table 2 are extracted from ARACIS standards and follow internal quality standards of top three universities from part-time and distance learning programmes (Figure 3 ).

Based on Table 2, coordinators have two perspectives: time management as coordinator and quality of required documents. From time management, the percentages shown in Figure 8 were determined based on an annual average of 360 hours (30 hours/month) and were monthly estimated. In each university payment average of coordinators was 40 lei/hour (leu (pl. lei) is Romanian currency). 
RECENT, Vol. 19, no. 3(56), December, 2018

Table 2. Human resources' activities: full-time vs part-time and distance learning

\begin{tabular}{|l|l|c|c|}
\hline Type of HR & \multicolumn{1}{|c|}{ Type of activities of HR } & $\begin{array}{c}\text { Full-time } \\
\text { programmes }\end{array}$ & $\begin{array}{c}\text { Part-time and distance } \\
\text { learning programmes }\end{array}$ \\
\hline \multirow{5}{*}{$\begin{array}{l}\text { Coordinator } \\
\text { of study } \\
\text { program }\end{array}$} & $\begin{array}{l}\text { Annual evaluation report } \\
\text { ponthly documents related to managerial } \\
\text { payment }\end{array}$ & yes & yes \\
\cline { 2 - 4 } & $\begin{array}{l}\text { Annual general documents: pay roll, } \\
\text { E-learning platform reports: twice/semester }\end{array}$ & no & yes \\
\cline { 2 - 4 } & E-learning platform handling - monthly & no & yes \\
\cline { 2 - 4 } & teaching staff' biannual evaluation: & yes & yes \\
\cline { 2 - 4 } & Evaluation report: once on every 4 or 5 years & yes & yes \\
\cline { 2 - 4 } & Certification / competencies & no & yes \\
\cline { 2 - 4 } & Activities' control & no & yes \\
\hline \multirow{5}{*}{$\begin{array}{l}\text { Teaching } \\
\text { staff }\end{array}$} & Curriculum & yes & yes \\
\cline { 2 - 4 } & Course teaching & yes & yes \\
\cline { 2 - 4 } & Discipline schedule & no & yes \\
\cline { 2 - 4 } & Teaching materials (distance learning & no & yes \\
\cline { 2 - 4 } & template) & no & yes \\
\cline { 2 - 4 } & ELearning platform activities & no & yes \\
\cline { 2 - 4 } & Week-end classes & yes \\
\cline { 2 - 4 } & Mandatory homework & no & no \\
\hline
\end{tabular}

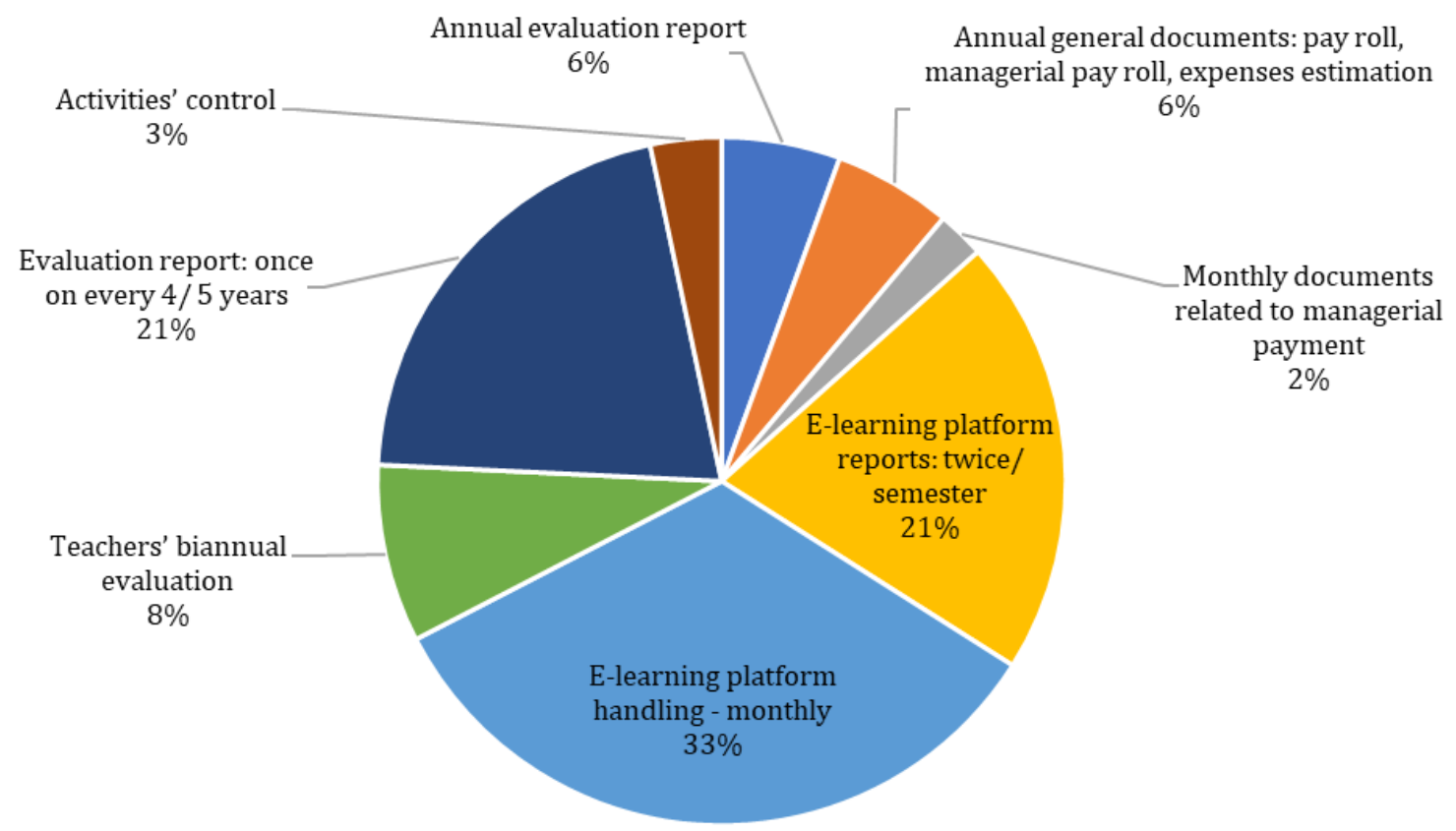

Fig. 8. Time consumption for coordinator of part-time / distance learning study programme

From payment point of view as ratio time spent vs payment, the responses were surprising (Figure 9). Thus, the payment, even if it is satisfactory, does not compensate the time spending.

Study focused also on teaching staff's payment. As average in the three university, for part-time and distance learning study programmes, teaching staff are payed with around 187.5 lei/conventional hour. The results are presented on Figure 10. As it can be seen there were opposite results from teaching staff' point of view as coordinators.

Relative to time management from teaching staff' point of view, the main activities that consume a lot of time are: eLearning activities, week-end classes and mandatory homework (Figure 11). 


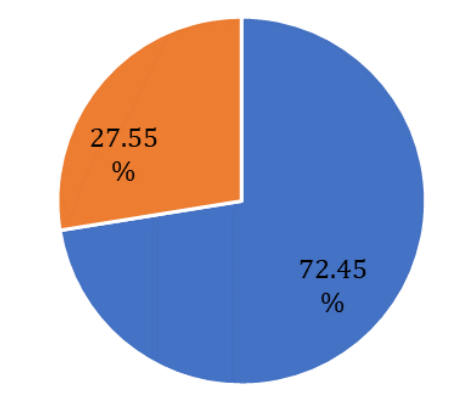

- Corresponding $=$ Not corresponding

Fig. 9. Coordinator payment satisfaction

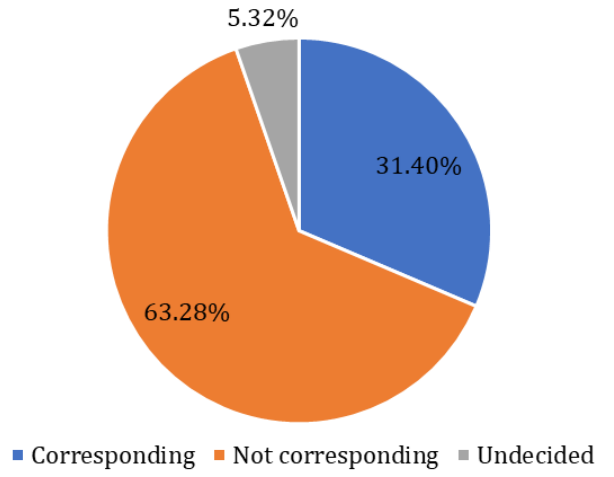

Fig. 10. Teaching staff payment satisfaction

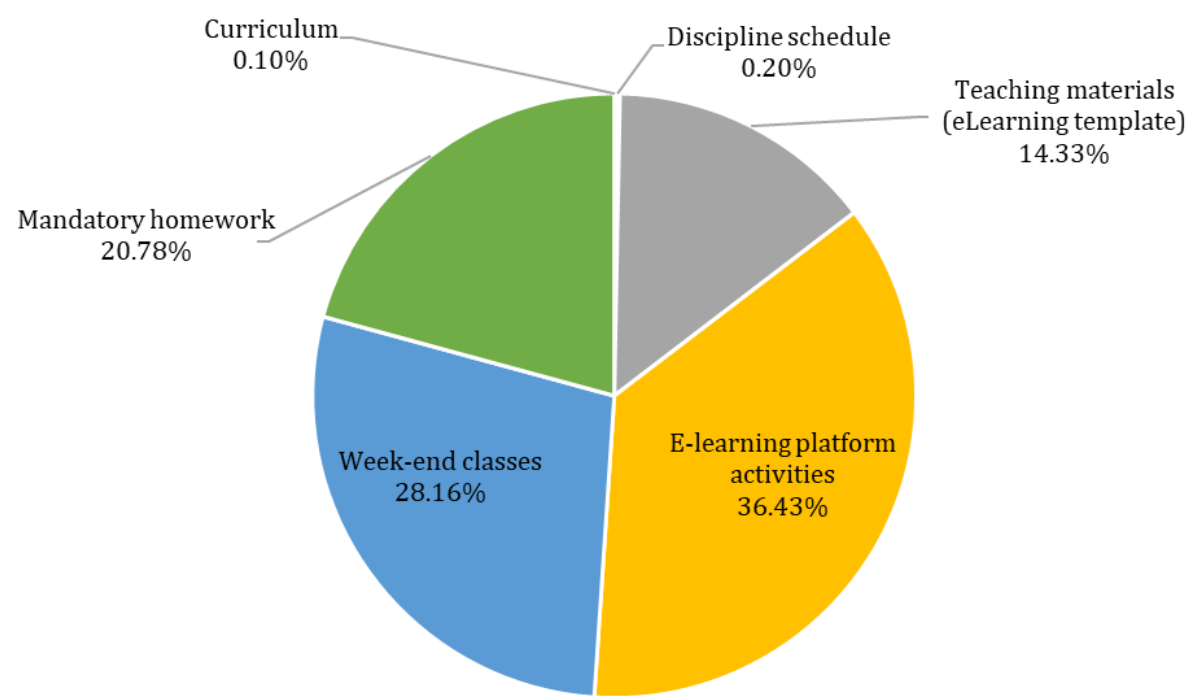

Fig. 11. Time consumption for teaching staff of part-time/ distance learning study programme

\section{Retention Planning and Conclusion}

The main impact of turnover is decrease of quality that may cause losing the accreditation and the costs of study programmes.

If we want to analyse the cost importance let's considering the following scenario:

- it is mandatory each teaching staff has to write a material in an eLearning template;

- assume that is paid for this material with around 2300 lei;

- consider study programmes with eight semesters (average of eight disciplines/semester), with a turnover rate of $75.60 \%$ (Figure 7).

Based on the above assumption, an optimistic scenario will be: 64 disciplines with 41 teaching staff; considering the turnover rate, will have, each year, an average of 10 new teaching staff, that will determine 10 new didactic materials. Thus, such a study programme will have, annually, a 23000 lei cost only with materials. If we consider and annual fee of 3000 lei and an average of 50 students/year, costs with didactic materials will represent 3.83\%.

The above scenario underlines the necessity of a retention plan. Retention planning it is very difficult to apply especially in state universities. It is very difficult also because the employees that universities wish to retain are often the ones most likely to leave. Retention strategies should be based on an understanding of the factors that affect whether or not employees leave or stay. According to $[3,5,6]$, employees may be grouped in three categories:

- early-career employees (30 years old and under) career advancement is significant;

- mid-career employees (age 31-50) the ability to manage their careers and satisfaction from their work are important;

- late-career employees (aged over 50) will be more interested in security. 
In the study presented in the paper, the percentage of late-career employees is just $13.45 \%$ and they have a very high stability index (2.1\% index). The highest turnover index is among early-career teaching staff $(54.67 \%)$ and after that mid-career teaching staff $(43.23 \%)$. Retention planning needs to make changes at several levels. In the context of new preferment standards in Romania, teaching staff' time is very limited, thus any solution that reduce time for specific activities in part-time/distance learning will bring a benefit for these programmes. Thus,

1. National level: transform blending learning, existing in Romania, in eLearning / distance learning, as it is in Europe and USA;

- Advantage:

$>$ week-end classes will be eliminated, all activities will switch on eLearning platform;

$>$ teaching staff may be employed based only on didactic activities from these programmes;

- Disadvantages:

$>$ high level of knowledge relative to eLearning platform;

$>$ high technology for on-line classes: both teaching staff and students should have technology high enough for on-line communication;

2. National level: include activity from these programmes in preferment standards (didactic activities);

- Advantage:

didactic requirements from preferment standards may be fulfilled with activities from these programmes;

$>$ reduce stress and time for didactic requirements because part-time and distance learning principles include, as mandatory a didactic material;

$>$ students from all study programmes may have didactic materials in the same template, easier to learn;

3. National level: implement an electronic evaluation of programmes, using eLearning platform;

- Advantage:

$>$ no printing documents;

$>$ less documents;

$>$ using electronic signature / documents signed and scanned;

$>$ low costs of evaluation (from universities point of view);

- Disadvantages:

$>$ coordinator is not able the explain some aspects regarding the programme;

4. University level: better payment of activities (both teaching and eLearning platform):

- Advantage:

$>$ better activity on eLearning platform;

$>$ reduce absenteeism on classes;

$>$ increase the interest on writing didactic material (eLearning template);

- Disadvantages:

$>$ increase de costs and force the management of the programmes to ensure stability of students;

5. University level: to have an appointee for eLearning platform (Transilvania University have these posts):

- Advantage:

$>$ release teaching staff of implement courses on eLearning platform;

$>$ release teaching staff to create different types of activities on eLearning platform;

$>$ help teaching staff with communication;

$>$ workshops on eLearning platform and thus help the coordinators also;

- Disadvantages:

$>$ increase de costs and number of managerial documents;

6. University level: create an informatic application that automatically generates some of the documents:

- Advantage:

$>$ easer update of documents; 
$>$ high level of correctness of documents;

$>$ reduce time both of teaching staff and coordinators;

- Disadvantages:

$>$ invest in programmers;

$>$ organise training sessions;

$>$ ensure maintenance of application;

$>$ available independent of type of study programmes.

Someone may ask if it is necessary to make effort (at specially at national level) to save part-time and distance learning study programmes. If it is considered that all the students enrolled in such programmes are paying annual fee, and this fee has an average of 3200 lei/year, these programmes become an important income source. For example: a distance learning programme with eight semesters, around 200 students, a 3000 lei annual fee, the income is 600,000 lei/year. If it is considering: 0.7 risk coefficient associated to fee non-payment (it will be considered only $70 \%$ of the theoretical fee income) and $40 \%$ for university on-costs, investments, result an income of around 252,000 lei/year. A study programme with eight semester has a pay roll (teaching staff and managerial) that costs around 190,000 lei/year. Thus, the faculty will have an income of 62,000 lei/year.

The solutions proposed in present paper at university level are efficient and with minimum costs but, based on the study, will increase the stability only with around $5 \%$. The main changes should be done at national level, included in standards and educational law.

\section{References}

1. ${ }^{* * *}$ : Romanian Education Law no. 1/2011, https://www.edu.ro/legislatie-organizare-și-funcționare-0 (in Romanian)

2. ***: 692/2018-09-05 Government decision, https://www.edu.ro/studii-licenta (in Romanian)

3. Armstrong M. (2012): Armstrong's Handbook of Human Resource Management Practice. British Library Cataloguing-in-Publication Data, ISBN 978-0-7494-6550-6

4. ***: ARACIS standards, http://www.aracis.ro/proceduri/ (in Romanian)

5. Emilian R., Tigu G., State O., Tuclea C.-E. (2003): Managementul resurselor umane (Human Resources Management). Editura ASE, ISBN 973-5-943-62X, https://www.scribd.com/doc/120543059/01-EmilianRadu-Managementul-Resurselor-Umane (in Romanian)

6. Maguad B.A., Krone R.M. (2017): Managing for Quality in Higher Education. Bookboon Publishing House, $2^{\text {nd }}$ ed., ISBN 978-87-403-1887-6, https://bookboon.com/en/managing-for-quality-in-higher-education-ebook 